\title{
Microwave synthesis of metal nanocatalysts for the electrochemical oxidation of small
} biomolecules

\author{
Jensen, Kathrine Schiørring Steen; Sun, Hongyu; Werchmeister, Rebecka Maria Larsen; Mølhave, \\ Kristian; Zhang, Jingdong
}

\author{
Published in: \\ Current Opinion in Electrochemistry
}

Link to article, DOI:

10.1016/j.coelec.2017.08.014

Publication date:

2017

Document Version

Peer reviewed version

Link back to DTU Orbit

Citation (APA):

Jensen, K. S. S., Sun, H., Werchmeister, R. M. L., Mølhave, K., \& Zhang, J. (2017). Microwave synthesis of metal nanocatalysts for the electrochemical oxidation of small biomolecules. Current Opinion in

Electrochemistry, 4(1), 124-132. https://doi.org/10.1016/j.coelec.2017.08.014

\section{General rights}

Copyright and moral rights for the publications made accessible in the public portal are retained by the authors and/or other copyright owners and it is a condition of accessing publications that users recognise and abide by the legal requirements associated with these rights.

- Users may download and print one copy of any publication from the public portal for the purpose of private study or research.

- You may not further distribute the material or use it for any profit-making activity or commercial gain

- You may freely distribute the URL identifying the publication in the public portal 


\section{Microwave synthesis of metal nanocatalysts for the electrochemical oxidation of small biomolecules}

Kathrine Schiørring Steen Jensen ${ }^{1}$, Hongyu Sun ${ }^{2}$, Rebecka Maria Larsen Werchmeister ${ }^{1}$, Kristian Mølhave ${ }^{2}$ and Jingdong Zhang ${ }^{1, *}$

\section{Address}

${ }^{1}$ Department of Chemistry, Technical University of Denmark, Kongens Lyngby 2800, Denmark

${ }^{2}$ Department of Micro- and Nanotechnology, Technical University of Denmark, Kongens Lyngby 2800, Denmark

Corresponding author: Zhang, Jingdong (jz@kemi.dtu.dk)

\section{Concise and factual abstract:}

Electrochemical oxidation of small biomolecules provides an approach to generate clean energy from a sustainable resource. It serves as a principle for anode reactions in fuel cells to convert energy stored in chemical bonds into electrical power. Efficient and robust nanocatalysts are essential to reduce the reaction barrier and accelerate the reaction kinetics. First the general aspects of electrochemical oxidation of small biomolecules are outlined and the green synthesis of metal particles by microwave synthesis is compared to conventional heating synthesis. Then recent progress in microwave-assisted nanocrystals used for electrochemical oxidation of small biomolecules is reviewed for alcohols, acids, and glucose. The challenges and future perspectives for the microwave synthesis as well as electrochemical oxidation of small biomolecules are discussed.

Keywords: metal nanocrystals; microwave synthesis; small biomolecules; electrocatalysts; fuel cells; green chemistry 


\section{Introduction}

Energy technologies with reduced resource consumption and lower pollution to the environment represent a core aspect of the sustainable development of modern society [1]. Especially in the chemical industry, useful chemicals are produced, accompanied by generation of waste and consumption of energy. Green Chemistry has been proposed with twelve fundamental principles to guide the implementation of renewable chemical processes [2]. Electrochemistry, i.e. electron transfer through an electrolyte/electrode interface to achieve a redox reaction, can match most of the principles involved in green chemistry [2, 3]. Specifically, oxidation of small biomolecules as fuels via an electrochemical route is an attractive alternative to obtain clean energy with renewability and high theoretical energy density [4]. Due to the complex multistep electron transfer processes involved, efficient catalysts for the electrochemical oxidation reactions are crucial [5-8] and the ways found to improve fuel cell processes may also aid in other energy conversion and chemical synthesis processes.

This review describes recent advances in electrochemical oxidation of small biomolecules assisted by metal nanocatalysts, which are sometimes called nanocrystals, nanoparticles (NPs) or nanostructures in the literature. Particularly we focus on metal nanocatalysts synthesized using a microwave-assisted strategy, which can be regarded as a green synthesis technique due to the high heating efficiency under optimal conditions where significant rate improvements over traditional heating methods are possible [9-11]. Microwave synthesis has previously been reviewed with emphasis on water as a green chemistry solvent and organic synthesis [12-14]. Given the at times considerable improvements in reaction efficiency and rates with microwaves over conventional heating, several possible non-thermal effects of microwaves have also been considered in previous reviews [15]. The main concept of the present review is microwave synthesis of materials for electrocatalysis using the nanocatalysts for cleaner energy conversion, Figure 1. A perspective on possible future directions of microwave synthesis is suggested. 


\section{Electrochemical oxidation of small biomolecules}

Small biomolecules, a class of organic molecules produced abundantly by plants, yeasts and bacteria in nature, primarily consist of carbon, hydrogen and oxygen, and to lesser extent other elements, such as phosphorous and sulfur. Typical small biomolecules are simple alcohols, polysaccharides, glucose and organic acids. Electrochemical oxidation of these molecules attracts great interest due to the perspective of direct oxidation-type fuel cells (DOFCs) for applications in electronic devices and transport vehicles $[4,16]$. Under ideal conditions, the products from the electrochemical oxidation of the small biomolecules should be pure $\mathrm{CO}_{2}$ and $\mathrm{H}_{2} \mathrm{O}$ to achieve the maximum possible chemical energy. The electrochemical oxidation of a small biomolecule consists of interfacial electron transfer, the diffusion of the molecules toward the electrode surface and the products' diffusion from the electrode. The whole process is kinetically slow due to the multiple complex process/reaction steps involving the formation of numerous adsorbed species and stable reaction products. The process can be significantly accelerated by introduction of efficient electrocatalysts $[17,18]$. The electrocatalysts are classified as inorganic, organic, enzymatic and microbial. Among them, inorganic catalysts, such as metal nanostructures, have been developed extensively due to their durability, high catalytic efficiency and stability.

Platinum $(\mathrm{Pt})$ is one of the most widely used catalysts for electrochemical oxidation and reduction reactions $[18,19]$. Pt catalysts possess the highest activity to dissociate adsorbed fuel molecules. On the other hand, the surfaces of Pt group catalysts (ruthenium $(\mathrm{Ru})$, rhodium $(\mathrm{Rh})$, palladium $(\mathrm{Pd})$, osmium $(\mathrm{Os})$, iridium (Ir), and Pt) are prone to be poisoned by possible byproducts created during oxidation reactions [20]. The poisoning results in steady degradation of the catalytic activity. To overcome this barrier, Pt-based bimetallic or multi-metallic catalysts have been designed with improved activity and stability toward the electrochemical oxidation reactions [20]. In general, synthesis of metal nanocatalysts with controllable size, morphology and composition is essential for optimizing the catalytic efficiency and reducing the total cost 
[21]. Wet chemical synthesis of metal nanocatalysts includes chemical reduction, seed formation/nucleation, growth, and stabilization by protection layers in solution. The geometric structures obtained and the properties of the nanocatalysts depend strongly on the synthesis conditions. Conventional heating for the syntheses using water/oil baths, hot plates or furnaces, will heat the solution from the outside, i.e. temperature increasing from outside toward the center of the solution [22]. In contrast, microwave synthesis is heating from the inside of the solution by microwave absorption (Figure 1). This technology has been advanced now over a decade.

\section{Microwave synthesis}

Microwave irradiation heating often leads to improved synthesis efficiency, enhanced sample purity and reduced energy consumption compared with the conventional heating methods [23]. Synthesis through this methodology can be scaled up for potential industrial applications when taking due care of the limited penetration depth of the absorbed microwaves [24]. The main principle of microwave-assisted synthesis is the selective absorption of microwave irradiation by mobile electric charges such as polar molecules or conducting ions in an electrolyte media [13], in which the reaction temperature is uniformly distributed by the spread-out dissipation of microwave irradiation energy (Figure 1) [25]. Moreover, the rate and efficiency of microwave irradiation heating are highly dependent on the properties of the reaction system [9]. In the liquid phase, solvent properties especially its polarity are important factors in microwave-assisted syntheses. Typical polar solvents with a high dipole moment, such as water, dimethylsulfoxide, ethylene glycol, dimethylformamide, and ionic liquids, are frequently used. In the early days of microwave synthesis, one had to be aware of the risk of explosions if the processes were not controlled properly, particularly for organic solvents with a low boiling point and a high vapor pressure. Today, warning systems or protection programs/devices have been integrated in state-of-the art microwave synthesizers. 
As a powerful synthesis method, microwave synthesis has been used for producing a number of inorganic compounds with various nanostructures [26-28]. A wide range of nanocatalysts based on Pt and their alloys or compounds have been successfully synthesized by employing microwaves (Figure 2). The geometrical parameters and chemical compositions of the nanocrystals can be well controlled by microwave reaction thermodynamics and kinetics by adjusting microwave conditions, precursor ratio and concentrations [29, 30]. For example, the size of the Pt nanocrystals is monodisperse and controlled by changing microwave irradiation time and monomer concentrations. The widely exploited strategies toward composition control rely on seed-mediated growth schemes. The nanocrystal morphologies depend on the relative growth rates of the exposed facets, which can be tuned by different approaches to inhibit or promote the growth of specific facets, such as space confinement, seed mediation, facet stabilization, or oriented attachment [31]. By controlling microwave reaction kinetics we have for example successfully synthesized thin $\mathrm{Pt}$ nanosheets, which is difficult to obtain by conventional heating methods. The thin nanosheets were characterized by transmission electron microscopy (TEM) and atomic resolution scanning tunneling microscopy (STM) (Figure 3). However, the ability to arbitrarily control the above parameters in nanocrystals by tuning microwave irradiation processes is still in its early stage as also largely for conventional synthesis processes. Systematic investigation and experience are accumulated step by step, and broader foundation of knowledge of microwave-assisted controllable syntheses is being established as the method also becomes more widespread in use.

\section{Electrochemical oxidation via microwave synthesized metal nanocrystals}

The oxidation of small biomolecules represents a class of important anode reactions in power generation devices, typically including direct methanol fuel cells (DMFCs), direct ethanol fuel cells (DEFCs), and direct formic acid fuel cells (DFAFCs). A series of multi-step processes, e.g., molecule adsorption, C-H or C-C bond cleavage, and the further oxidation of byproducts, are involved. Pt or Pd based noble metals, 
non-noble metals, and their alloys or compounds have been designed based on well-established principles, including the electronic effects and structure effects [4-8], to achieve good activity and durability. The structure effect are important to understand the effects of exposed facets, steps, kinks, etc. on the catalytic activity. The electronic effects determine the electronic status of active sites, which are realized by tuning the local chemical composition. Recent progress on the oxidation of some important small biomolecules (alcohols, organic acids, glucose, etc) catalyzed by microwave synthesized metal nanocrystals is discussed in the following and summarized in Table $\mathbf{1}$ and Table $\mathbf{2}$ that also provide a comparison of the typical rates and efficiencies achieved.

Electrochemical oxidation of alcohols. Pt is the most efficient catalyst used for a number of electrochemical oxidation reactions [11, 12]. As a typical example, Liu et al. [42] synthesized polymer-free $\mathrm{Pt}$ nanoparticles/graphene nanosheets by microwave-assisted reduction of graphene oxide (GO) and $\mathrm{H}_{2} \mathrm{PtCl}_{6}$, in which ethylene glycol served as a reducing agent and solvent. The microwave irradiation time was 2 min under a power of $750 \mathrm{~W}$. The catalytic activity of the particles toward methanol oxidation was further demonstrated. On the other hand, the scarce nature and high cost of pure Pt catalyst, as well as the risk of poisoning, hinder its more widespread application. Alloying Pt with cheaper transition metals is a powerful route to approach this problem $[20,21]$. To date, Pt- or Pd based alloy or compounds, such as PtNi, PtCo, PtMn, PtPb, PtRu, PtSn, PdNi, PdFe, PdMn, PdRu, PdSn, etc., have been successfully synthesized by the microwave-assisted method [30, 34, 38, 39, 41, 44-46, 49-51, 53-55]. Compared to the corresponding monometal catalysts, these alloys or compounds show higher electrochemical activity and durability in electrochemical oxidation of methanol, ethanol, and other polyalcohols.

A comparison of the conventional heat-treatment and microwave irradiation method was reported by Mathe et al. [39] who synthesized PtM ( $\mathrm{M}=\mathrm{Co}, \mathrm{Ni})$ bimetallic alloys using both methods and found that the alloy 
structure/composition and the electrochemical methanol oxidation properties are directly related to the synthesis process. Firstly, X-ray diffraction and X-ray photoelectron spectroscopy results confirmed that alloyed structures with surface segregation of $\mathrm{Co}$ and $\mathrm{Ni}$ were formed in the microwave synthesized samples. In contrast, the conventional heat treated catalysts showed Pt surface segregation. Secondly, the microwave synthesized PtNi catalyst displayed a better activity towards methanol oxidation, due to large amounts of Ni-hydroxide species observed on the catalyst surface.

Nassr and Born et al. [44] compared the catalytic properties of PtNi nanoparticles supported on oxygen functionalized carbon nanotubes, which were synthesized by microwave-assisted methods through two different irradiation modes, i.e., continuous and pulsed irradiation. It was found that the irradiation mode influenced the metal loading and the activity of the as-prepared catalysts, and the samples formed under continuous irradiation showed the highest electrocatalytic activity for methanol oxidation, caused by the electronic effect. [44]. Palma and co-authors [30] reported multimetallic Pt-based electrocatalysts (PtNi, PtRu, PtRuNi, PtSnRuNi) supported on carbon prepared by the microwave-assisted heating method. Of all the samples, the $\mathrm{Pt}_{75} \mathrm{Sn}_{13} \mathrm{Ru}_{11} \mathrm{Ni} / \mathrm{C}$ catalysts showed the best performance in the DEFCs test. Recent studies (see Table 1, 2) show that the synergy interactions between Pt and transition metal oxides or metal hydroxides promote the oxidation of intermediate carbon containing small molecules by providing oxygen species. Huang et al. [36] synthesized $\mathrm{Pt} / \mathrm{Ni}(\mathrm{OH})_{2} / \mathrm{rGO}$ ternary hybrids through a rapid microwave treatment $(90 \mathrm{~s})$. Through collective synergy, the three functional components in the hybrid materials together showed high activity and durability for the methanol oxidation reaction. Besides the electrochemical oxidation of simple alcohols, Pt- or Pd based alloys (PtPb, PtRu, PdRu, PdNi, PdSn, PdMn, PdFe) obtained by microwave synthesis show surprisingly high catalytic activity in the oxidation of polyalcohols (ethylene glycol, glycerol, etc) [35, 49, 50]. 
Catalysts without Pt are also being developed. Abdel Hameed et al. [40] prepared Ni nanoparticles on carbon black by combining wet chemical deposition with microwave irradiation. In that study the optimized $\mathrm{Ni}$ catalyst $(30 \mathrm{wt} . \% \mathrm{Ni} / \mathrm{C})$ showed the highest electrocatalytic activity towards methanol oxidation.

Electrochemical oxidation of organic acids. Typical organic acids including formic acid, acetic acid and ascorbic acid, are potential fuels in DOFC devices. Generally, organic acid oxidation reactions on catalytic electrodes undergo a dual-path mechanism: (1) through direct oxidation to produce $\mathrm{CO}_{2}$, and (2) through formation of $\mathrm{CO}_{\text {ads }}$ and the subsequent oxidation of $\mathrm{CO}_{\text {ads }}$ to $\mathrm{CO}_{2}$ at higher potentials. Among pure metals, Pd shows better catalytic activity than Pt toward the oxidation of organic acids. For example, $\mathrm{Pd}$ and $\mathrm{Pt}$ nanoparticles on Vulcan XC-72 carbon were produced by a microwave-assisted polyol process (700 W, $50 \mathrm{~s}$ ) [52]. Tested as anode catalysts in a DFAFC device at room temperature, the open-circuit voltages of the cells using $\mathrm{Pd} / \mathrm{C}$ and $\mathrm{Pt} / \mathrm{C}$ catalysts were 0.74 and $0.685 \mathrm{~V}$, respectively, while the corresponding peak power densities are 120 and $76.5 \mathrm{~mW} \mathrm{~cm}{ }^{-2}$. However, Pd catalysts are vulnerable to acidic conditions in practical applications. Pt and Pt-based alloys (PtPb, PtAu, PtSn, etc), which show high tolerance to acidic environments, are therefore widely used as electrocatalysts to oxidize organic acids. Recently, Cabello and co-workers [51] reported microwave-assisted hydrothermal synthesis of bimetallic PtAu nanoparticles with different $\mathrm{Pt} / \mathrm{Au}$ ratios. PtAu alloys showed better activity than bulk $\mathrm{Pt}$ or even $\mathrm{Pt}$ nanoparticles used as electrocatalysts for the oxidation of formic acid in terms of onset potential and peak current density.

Electrochemical oxidation of glucose. The electrochemical oxidation of glucose attracts much attention due to the fact that glucose containing six carbon atoms is produced abundantly by plants. Hydrolysis of starch can produce large amounts of glucose at low cost. Theoretically, the total oxidation of glucose to $\mathrm{CO}_{2}$ includes 24 electron transfer steps. Glucose oxidase is a redox enzyme which can selectively catalyze 
electrochemical oxidation of glucose to gluconic acid, but this reaction often requires the presence of a mediator to facilitate the electron transfer to an electrode. Developing metal based nanocatalysts for glucose is challenging and progressing steadily. Pt and Pd have been tested for activity for the glucose oxidation reaction, but unfortunately the catalytic activity gradually degrades due to a risk of poisoning. In this respect, alloys based on the combination of noble and non-noble metals have shown more robust and active catalysis. Carbon supported PdAu binary catalysts were made by a modified pulse microwave assisted polyol method. The PdAu alloy with a Pd/Au ratio of 30/70 showed desirable electrochemical performance, considering current density, overpotential and poison tolerance [53]. This modified pulse microwave assisted polyol method is also successfully used for the synthesis of other alloy nanocatalysts such as PdRh [55], with electrocatalytic activity toward oxidation of glucose and with a potential for the development of direct glucose fuel cells.

\section{Perspectives}

Electrochemical oxidations of small biomolecules are multi-step processes that depend strongly on the properties of the catalysts. The past decade has witnessed the rapid development of design and synthesis of a wide range of anode nanocatalysts through microwave-assisted synthesis. However, some fundamental challenges of microwave synthesis clearly should be addressed in the near future: (1) precise control of the microstructures (size, morphology, composition, etc.) and assembly of the microwave synthesized nanostructures; (2) the understanding of the detailed nucleation and growth mechanisms in liquid phase under microwave irradiation; (3) investigation on scaling up microwave-assisted large-scale synthesis. (4) Understanding why and when the microwave method is better than conventional heating methods.

For commercialization of the nanocatalysts as anode materials in fuel cells, excellent performance, cost of the synthesis, and environmental impact are all factors that are important to assess. To enhance fundamental 
understanding of the nanocatalysts, the following aspects are currently pursued: (1) performing in-situ/operando spectroscopic or microscopic studies to directly trace the evolution of catalysts in real working conditions, which is crucial to study the catalyst degradation as well as the catalytic mechanism [56]. (2) theoretical studies, for example density functional theory calculations and molecular dynamic simulations, will help us to understand the atomic scale catalytic mechanism and design ideal catalyst materials [57]. (3) as a long-term perspective, biocatalysts such as enzymes and microbial organisms are expected to be developed in combination of biomolecules and/or systems with metal nanocatalysts to increase their stability, durability and efficiency in oxidation processes of fuel molecules.

\section{Acknowledgments}

Financial support from the Danish Council for Independent Research for FTP project (DFF - 1335-00330) and YDUN project (DFF 4093-00297) to JZ and FTP project (12-126194) to KM is acknowledged.

\section{References and recommended reading}

Papers of particular interest, published within the period of review, have been highlighted as:

- Paper of special interest.

.. Paper of outstanding interest.

1. Schultz DM, Yoon TP: Solar synthesis: prospects in visible light photocatalysis. Science 2014, 343:1239176/1-8.

2. Anastas PT, Warner J: Green chemistry: theory and practice. Oxford University Press, Oxford, 1998.

3. Shen PK, Wang CY, Jiang SP, Sun XL, Zhang JJ: Electrochemical energy: advanced materials and technologies. CRC Press, Boca Raton, FL, 2016.

4. Vielstich W, Gasteiger HA, Lamm A, Yokokawa H: Handbook of fuel cells- fundamentals, technology and applications. John Wiley \& Sons, Ltd, 2010.

5. Wu L, Moteki T, Gokhale AA, Flaherty DW, Toste FD: Production of fuels and chemicals from biomass: condensation reactions and beyond. Chem 2016, 32:32-58.

.. This article summarizes both the biological and chemical catalytic routes to producing platform chemicals from renewable sources and describes advances in condensation chemistry and strategies for the conversion of these platform chemicals into fuels and high-value chemicals.

6. Mistry H, Varela AS, Kühl S, Strasser P, Cuenya BR: Nanostructured electrocatalysts with tunable activity and selectivity. Nature Rev Mater 2016, 1:1-14.

7. Debe MK: Electrocatalyst approaches and challenges for automotive fuel cells. Nature 2012, 
486:43-51.

.. This important review is provided from the perspective of a fuel-cell component supplier who needs to consider all factors (such as catalytic activity, manufacture, cost, and so on) that any electrocatalyst approach will need to meet if it is to be commercially successful.

8. Montoya JH, Seitz LC, Chakthranont P, Vojvodic A, Jaramillo TF, Nørskov JK: Materials for solar fuels and chemicals. Nature Mater 2016, 16:70-81.

9. Hoogenboom R, Wilms TFA, Erdmenger T, Schubert US: Microwave-assisted chemistry: a closer look at heating efficiency. Aust $J$ Chem 2009, 62:236-243.

10. Cho H, Török F, Török B: Energy efficiency of heterogeneous catalytic microwave-assisted organic reactions. Green Chem 2014, 16:3623-3634.

11. Kappe CO: Controlled microwave heating in modern organic synthesis. Angew Chem Int Ed 2004, 43:6250-6284.

12. https://www.soc.chim.it/sites/default/files/chimind/pdf/2012 478 ca.pdf, and references cited therein.

13. Dallinger D, Kappe CO: Microwave-assisted synthesis in water as solvent. Chem Rev 2007, 107:2563-2591.

14. Kappe CO: Controlled microwave heating in modern organic synthesis. Angew Chem Int Ed 2004, 43:6250-6284.

15. Hoz A, Díaz-Ortiz Á, Moreno A: Microwaves in organic synthesis. thermal and non-thermal microwave effects. Chem Soc Rev 2005, 34:164-178.

16. Kulesza PJ, Pieta IS, Rutkowska IA, Wadas A, Marks D, Klak K, Stobinski L, Cox JA: Electrocatalytic oxidation of small organic molecules in acid medium: Enhancement of activity of noble metal nanoparticles and their alloys by supporting or modifying them with metal oxides. Electrochim Acta 2013, 110:474-483.

17. Liang ZX, Zhao TS: Catalysts for alcohol-fuelled direct oxidation fuel cells. The Royal Society of Chemistry, Cambridge, UK, 2012.

18. Rabis A, Rodriguez P, Schmidt TJ: Electrocatalysis for polymer electrolyte fuel cells: recent achievements and future challenges. ACS catal 2012, 2:864-890.

19. Xu Y, Zhang B: Recent advances in porous Pt-based nanostructures: synthesis and electrochemical applications. Chem Soc Rev 2014, 43:2439-2450.

20. Wang YJ, Zhao N, Fang B, Li H, Bi XT, Wang H: Carbon-supported Pt-based alloy electrocatalysts for the oxygen reduction reaction in polymer electrolyte membrane fuel cells: particle size, shape, and composition manipulation and their impact to activity. Chem Rev 2015, 115:3433-3467.

21. Chen A, Holt-Hindle P: Platinum-based nanostructured materials: synthesis, properties, and applications. Chem Rev 2010, 110:3767-3804.

22. Duan H, Wang D, Li Y: Green chemistry for nanoparticle synthesis. Chem Soc Rev 2015, 44:5778-5792.

23. Schanche JS: Microwave synthesis solutions from personal chemistry. Mol Divers 2003, 7:293-300.

24. Morschhäuser R, Krull M, Kayser C, Boberski C, Bierbaum R, Pü schner PA, Glasnov TN, Kappe CO: Microwave-assisted continuous flow synthesis on industrial scale. Green Process Synth 2012, 1: 281-290.

25. Kitchen HJ, Vallance SR, Kennedy JL, Tapia-Ruiz N, Carassiti L, Harrison A, Whittaker AG, Drysdale TD, Kingman SW, Gregory DH: Modern microwave methods in solid-state inorganic materials chemistry: from fundamentals to manufacturing. Chem Rev 2014, 114:1170-1206.

.. This important review paper shows the significant advances in the area of microwave-irradiation synthesis with an emphasis on the opening period of the 21st century.

26. Baghbanzadeh M, Carbone L, Cozzoli PD, Kappe CO: Microwave-assisted synthesis of colloidal inorganic nanocrystals. Angew Chem Int Ed 2011, 50:11312-11359. 
.. This review article illustrates microwave-assisted methods that have been developed to synthesize colloidal inorganic nanocrystals and critically evaluates the specific roles that microwave irradiation may play in the formation of these nanomaterials.

27. Gawande MB, Shelke SN, Zboril R, Varma RS: Microwave-assisted chemistry: synthetic applications for rapid assembly of nanomaterials and organics. Acc Chem Res 2014, 47:1338-1348.

28. Butt FK, Bandarenka AS: Microwave-assisted synthesis of functional electrode materials for energy applications. J Solid State Electrochem 2016, 20:2915-2928.

29. Higgins DC, Ye SY, Knights S, Chen ZW: Highly durable platinum-cobalt nanowires by microwave irradiation as oxygen reduction catalyst for PEM fuel cell. Electrochem Solid-State Lett 2012, 15:B83-B85.

- One dimensional Pt-Co alloy nanowires were synthesized by microwave-irradiation process.

30. Palma LM, Almeida TS, Leonello PH, De Andrade AR: Ethanol electrooxidation by plurimetallic Pt-based electrocatalysts prepared by microwave assisted heating. J Electroche Soc 2014, 161:F473-F479.

- This paper reports on electrocatalysts supported on carbon containing 40 wt\% metal loading of $\mathrm{Pt}, \mathrm{Ru}, \mathrm{Ni}$, and $\mathrm{Sn}$ prepared by microwave-assisted heating. Ethanol electrolysis and the related products are analysized.

31. Thanh NTK, Maclean N, Mahiddine S: Mechanisms of nucleation and growth of nanoparticles in solution. Chem Rev 2014, 114:7610-7630.

32. Lee JY, Yung TY, Liu LK: The microwave-assisted ionic liquid nanocomposite synthesis: platinum nanoparticles on graphene and the application on hydrogenation of styrene. Nanoscale Res Lett 2013, 8:414-419.

33. Dahal N, García S, Zhou JP, Humphrey SM: Beneficial effects of microwave-assisted heating versus conventional heating in noble metal nanoparticle synthesis. ACSNano 2012, 6:9433-9446.

.. This paper show an extensive comparative study of the effects of microwave versus conventional heating on the nucleation and growth of near-monodisperse $\mathrm{Rh}, \mathrm{Pd}$, and Pt nanoparticles. The effect of heating modes on the nucleation and nanoparticle growth kinetics is studied in detail.

34. Bensebaa F, Farah AA, Wang DS, Bock C, Du XM, Kung J, Page YL: Microwave synthesis of polymer-embedded Pt-Ru catalyst for direct methanol fuel cell. J Phys Chem B 2005, 109:15339-15344.

35. Fashedemi OO, Miller HA, Marchionni A, Vizza F, Ozoemena KI: Electro-oxidation of ethylene glycol and glycerol at palladium-decorated FeCo@Fe core-shell nanocatalysts for alkaline direct alcohol fuel cells: functionalized MWCNT supports and impact on product selectivity. J Mater Chem A 2015, 3:7145-7156.

36. Huang WJ, Wang HT, Zhou JG, Wang J, Duchesne PN, Muir D, Zhang P, Han N, Zhao FP, Zeng M, Zhong J, Jin $\mathrm{CH}$, Li YG, Lee ST, Dai HJ: Highly active and durable methanol oxidation electrocatalyst based on the synergy of platinum-nickel hydroxide-graphene. Nature Commun 2015, 6:10035/1-8.

- Pt-Ni(OH) 2 -graphene ternary hybrids synthesized by microwave-assisted heating show improved activity and durability for methanol oxidation reaction. The incorporation of highly defective $\mathrm{Ni}(\mathrm{OH})_{2}$ plays the decisive role in promoting the dissociative adsorption of water molecules and subsequent oxidative removal of carbonaceous poison on neighbouring platinum sites.

37. Mohamed MB, AbouZeid KM, Abdelsayed V, Aljarash AA, El-Shall MS: Growth mechanism of anisotropic gold nanocrystals via microwave synthesis: formation of dioleamide by gold nanocatalysis. ACSNano 2010, 4:2766-2772.

- This paper demonstrates the size, shape, and morphology of the Au nanocrystals can be controlled by varying the microwave reaction parameters, including the ratio of mixed solvents (oleylamine, oleic acid), the microwave time, and the concentration of the gold ions.

38. Huang YY, Zheng SY, Lin XJ, Su LQ, Guo YL: Microwave synthesis and electrochemical performance of a PtPb alloy catalyst for methanol and formic acid oxidation. Electrochim Acta 2012, 63:346-353. 
39. Mathe NR, Scriba MR, Coville NJ: Methanol oxidation reaction activity of microwave- irradiated and heat-treated Pt/Co and Pt/Ni nano-electrocatalysts. Int J Hydrogen Energy 2014, 39:18871-18881.

.. This paper compares the microstructure and methanol oxidation reaction activity of Pt-based alloys synthesized by conventional heat-treatment $(\mathrm{HT})$ method and microwave-irradiation (MW). The Pt-based alloys obtained by MW method show better electrocatalytic properties toward the oxidation of methanol.

40. Abdel Hameed RM, El-Sherif RM: Microwave irradiated nickel nanoparticles on Vulcan XC-72R carbonblack for methanol oxidation reaction in KOH solution. Appl Catal B Environ 2015, 162:217-226.

41. Zhao D, Shi MQ, Liu WM, Chu YQ, Ma CA: Special microwave-assisted one-pot synthesis of low loading Pt-Ru alloy nanoparticles on reduced graphene oxide for methanol oxidation. Micro \& Nano Lett 2014, 9:50-54.

42. Liu S, Wang L, Tian JQ, Lu WB, Zhang YW, Wang XD, Sun XP: Microwave-assisted rapid synthesis of $\mathrm{Pt} / \mathrm{graphene}$ nanosheet composites and their application for methanol oxidation. J Nanopart Res 2011, 13:4731-4737.

43. Ye LT, Li ZS, Zhang XF, Lei FL, Lin S: One-step microwave synthesis of $\mathrm{Pt}(\mathrm{Pd}) / \mathrm{Cu}_{2} \mathrm{O} / \mathrm{GNs}$ composites and their electro-photosynergistic catalytic properties for methanol oxidation. J Mater Chem A 2014, 2:21010-21019.

44. Nassr ABAA, Sinev I, Pohl MM, Grünert W, Bron M: Rapid microwave-assisted polyol reduction for the preparation of highly active PtNi/CNT electrocatalysts for methanol oxidation. ACS Catal 2014, 4:2449-2462

45. Nassr ABAA, Bron M: Microwave-assisted ethanol reduction as a new method for the preparation of highly active and stable CNT- supported PtRu electrocatalysts for methanol oxidation. ChemCatChem 2013, 5:1472-1480.

46. Almeida TS, Palma LM, Leonello PH, Morais C, Kokoh KB, De Andrade AR: An optimization study of $\mathrm{PtSn} / \mathrm{C}$ catalysts applied to direct ethanol fuel cell: effect of the preparation method on the electrocatalytic activity of the catalysts. J Power Sources 2012, 215:53-62.

47. Russo PA, Ahn M, Sung YE, Pinna N: Improved electrocatalytic stability in ethanol oxidation by microwave-assisted selective deposition of $\mathrm{SnO}_{2}$ and Pt onto carbon. RSC Adv 2013, 3:7001-7008.

48. Rohwer MB, Modibedi RM, Ozoemena $\mathrm{Kl}$ : Microwave activation of palladium nanoparticles for enhanced ethanol electrocatalytic oxidation reaction in alkaline medium. Electroanalysis 2015, 27:957-963.

49. Palma LM, Almeida TS, De Andrade AR: High catalytic activity for glycerol electrooxidation by binary Pd-based nanoparticles in alkaline media. ECS Trans 2013, 58:651-661.

50. Palma LM, Almeida TS, Morais C, Napporn TW, Boniface Kokoh K, de Andrade AR: Effect of Co-catalyst on the selective electrooxidation of glycerol over ruthenium-based nanomaterials. ChemElectroChem 2017, 4:39-45.

51. Cabello G, Davoglio RA, Hartl FW, Marco JF, Pereira EC, Biaggio SR, Varela H, Cuesta A: Microwave-assisted synthesis of Pt-Au nanoparticles with enhanced electrocatalytic activity for the oxidation of formic acid. Electrochim Acta 2017, 224:56-63.

52. Liu ZL, Hong L, Tham MP, Lim TH, Jiang HX: Nanostructured Pt/C and Pd/C catalysts for direct formic acid fuel cells. J Power Sources 2006, 161:831-835.

53. Yan LL, Brouzgou A, Meng YZ, Xiao M, Tsiakaras P, Song SQ: Efficient and poison-tolerant $\mathbf{P d} \mathbf{d}_{\mathbf{x}} \mathbf{A} \mathbf{u}_{\mathbf{y}} / \mathbf{C}$ binary electrocatalysts for glucose electrooxidation in alkaline medium. Appl Catal B Environ 2014, 150-151:268-274.

54. Jiang TT, Yan LL, Meng YZ, Xiao M, Wu ZR, Tsiakaras P, Song SQ: Glucose electrooxidation in alkaline medium: Performanceenhancement of $\mathrm{PdAu} / \mathrm{C}$ synthesized by $\mathrm{NH}_{3}$ modified pulse microwave assisted polyol method. Appl Catal B Environ 2015, 162:275-281. 
55. Brouzgou A, Yan LL, Song SQ, Tsiakaras $P$ : Glucose electrooxidation over $\mathbf{P d} \mathbf{d}_{\mathbf{x}} \mathbf{R h} / \mathbf{C}$ electrocatalysts inalkaline medium. Appl Catal B Environ 2014, 147:481-489.

56. Ross FM: Opportunities and challenges in liquid cell electron microscopy. Science 2015, 350:aaa9886/1-9.

57. Sej ZW, Kibsgaard J, Dickens CF, Chorkendorff I, Nørskov JK, Jaramillo TF: Combining theory and experiment in electrocatalysis: Insights into materials design. Science 2017, 355:eaad4998/1-12. 
Figure Legends

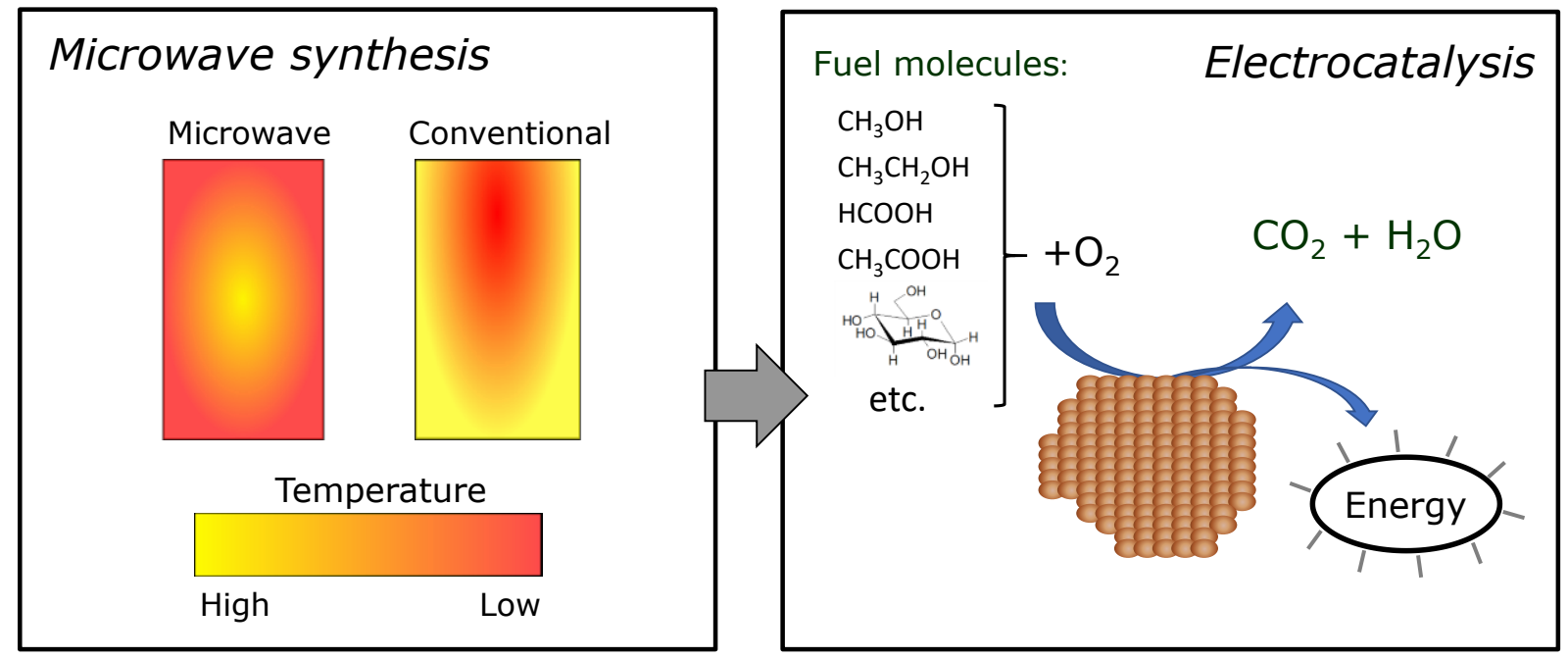

Figure 1 Schematic representation of core concepts. Left: Microwave synthesis. Right: Electrocatalysis of a nanocatalyst for oxidation of fuel molecules and generation of energy. 

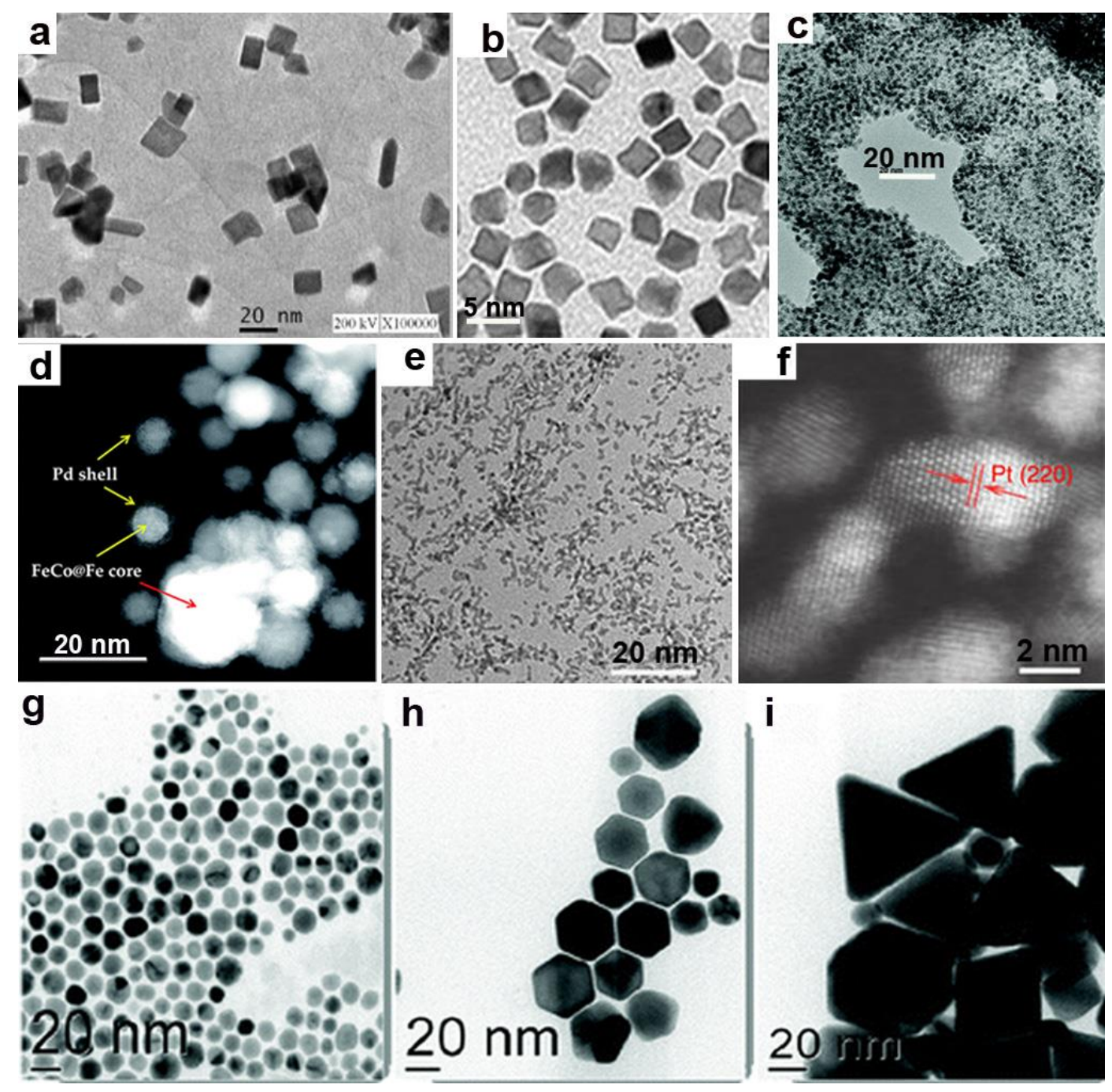

Figure 2 Electron microscopy images of microwave synthesized metal nanocrystals: (a) cube-like $\mathrm{Pt}$ nanoparticles on reduced graphene oxide nanosheet. (Adapted with permission from ref [32], Springer, Open Access); (b) Rh nanoparticles. (Adapted with permission from ref [33]. Copyright 2012 American Chemical Society); (c) Pt-Ru nanoparticles. (Adapted with permission from ref [34]. Copyright 2005 American Chemical Society); (d) FeCo@Fe@Pd nanoparticles (Adapted with permission from ref [35]. Copyright 2015 The Royal Society of Chemistry); (e, f) Pt/Ni(OH)$)_{2}$ nanoparticles on reduced graphene oxide nanosheet. (Adapted with permission from ref [36]. Copyright 2015 The Nature Publishing Group); Au nanoparticles with different shapes formed using (g) dioleamide only, (h) a 1:1 molar ratio of dioleamide and oleic acid, and (i) a 1:2 molar ratio of dioleamide and oleic acid. (Adapted with permission from ref [37]. Copyright 2010 American Chemical Society). 

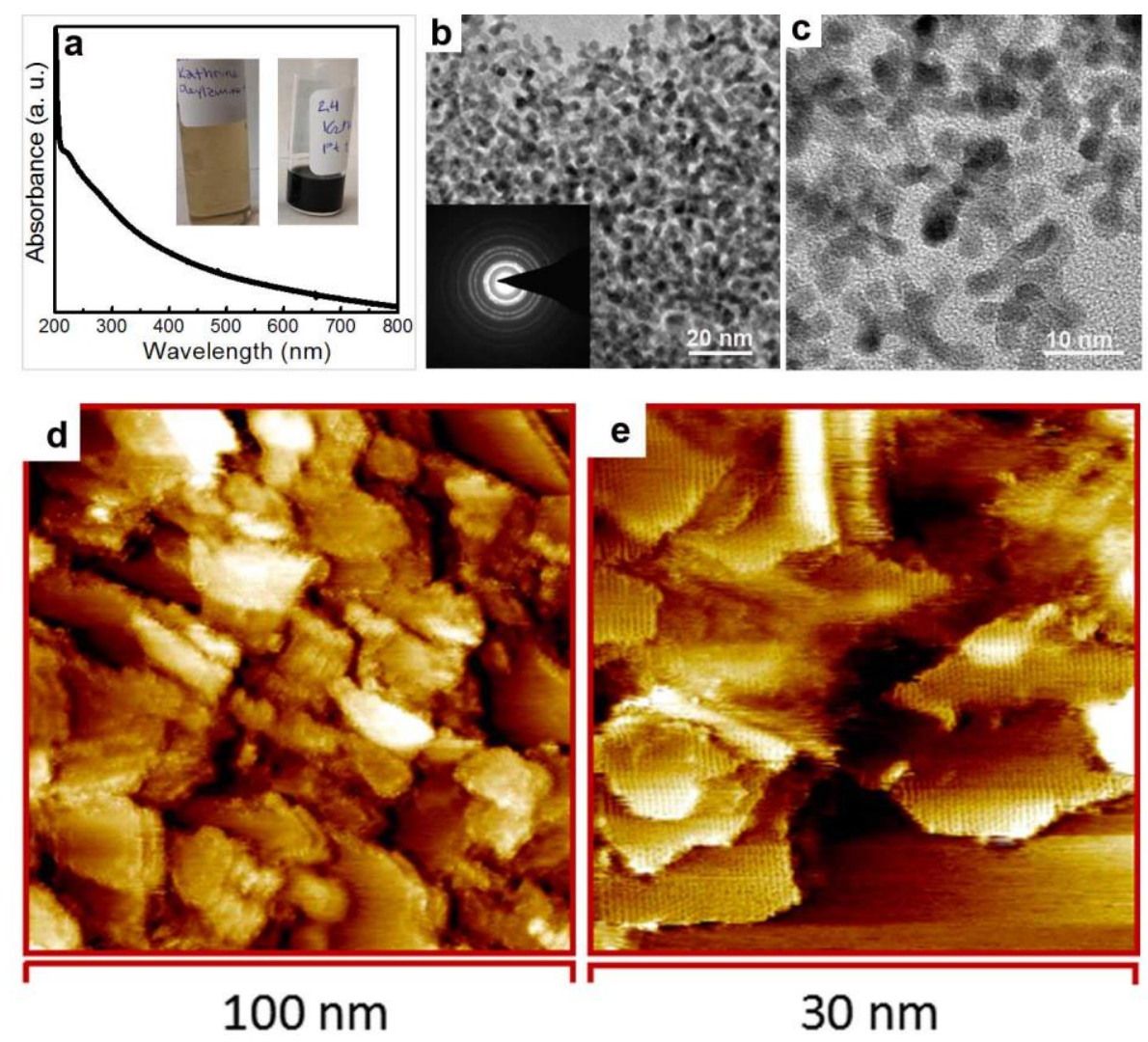

Figure 3 (a) Typical UV-Vis spectrum of Pt nanosheets prepared by microwave-assisted heating method at $170{ }^{\circ} \mathrm{C}$ for 6 hours in a mixture of $6 \mathrm{~mL}$ isopropanol, $6 \mathrm{~mL}$ oleylamine and $7.5 \mathrm{mg}$ platinum(II) acetylacetonate. The inset photographs are the reaction solution after the product has been removed (left) and the purified product dispersed in hexane (right); (b, c) TEM images of the Pt nanosheets; (d, e) STM images of Pt nanosheets immobilized on highly oriented pyrolytic graphite (HOPG) surface. Data from the authors. 
Table 1 Microwave-assisted synthesis of typical metal nanocatalysts for electrochemical oxidation of simple alcohols. MO: methanol oxidation; EO: ethanol oxidation; EGO: ethylene glycol oxidation; GLYO: glycerol oxidation; EG: ethylene glycol. $I_{\mathrm{f}}$ : forward peak current; $I_{\mathrm{b}}$ : backward peak current; $E_{\mathrm{f}}$ : forward peak potential; $E_{\text {onset: }}$ onset overpotential; $I_{\text {mass: }}$ mass activity.

\begin{tabular}{|c|c|c|c|c|c|}
\hline Metal & Precursors & Reaction conditions & Size/morphology & Catalytic properties & Ref. \\
\hline $\mathrm{PtPb}$ & $\begin{array}{l}\mathrm{H}_{2} \mathrm{PtCl}_{6,} \\
\mathrm{~Pb}\left(\mathrm{CH}_{3} \mathrm{COO}\right)_{2,} \\
\text { EG }\end{array}$ & $800 \mathrm{~W}-90 \mathrm{~s}-5 \mathrm{~min}$ & $5.9 \mathrm{~nm}$ spheres & $\begin{array}{l}\text { MO: } \\
I_{\mathrm{f}}=1533.7 \mathrm{~mA} \mathrm{mg}^{-1} \mathrm{Pt}\end{array}$ & 38 \\
\hline PtCo & $\mathrm{CoCl}_{2}, \mathrm{NiCl}_{2}$ & $250^{\circ} \mathrm{C}-750 \mathrm{~W}-30$ & network of bead like & MO: & 39 \\
\hline PtNi & $\begin{array}{l}\mathrm{H}_{2} \mathrm{PtCl}_{6}, \mathrm{EG} \\
\mathrm{NaOH}\end{array}$ & $\min$ & nanoparticles & $\begin{array}{l}I_{\mathrm{f}}=1.68 \mathrm{~mA} \mathrm{~cm}^{-2}(\mathrm{PtCo}) \\
55.4 \mathrm{~mA} \mathrm{~cm}^{-2}(\mathrm{PtNi})\end{array}$ & \\
\hline $\mathrm{Ni}$ & $\mathrm{NiCl}_{2}, \mathrm{NaBH}_{4}$ & $\begin{array}{l}\text { pulse mode } 50 \mathrm{MHz} \text {, } \\
1400 \mathrm{~W} \text { - } 5 \mathrm{~min}\end{array}$ & $6 \mathrm{~nm}$ particles & $\begin{array}{l}\text { MO: } \\
I_{\mathrm{f}}=30 \mathrm{~mA} \mathrm{~cm}^{-2}\end{array}$ & 40 \\
\hline PtRu & $\begin{array}{l}\mathrm{H}_{2} \mathrm{PtCl}_{6,} \\
\mathrm{RuCl}_{3}, \mathrm{EG}\end{array}$ & $120^{\circ} \mathrm{C}-20 \mathrm{~min}$ & $1.85-4.15 \mathrm{~nm}$ particles & $\begin{array}{l}\text { MO: } \\
I_{\mathrm{f}}=1231.7 \mathrm{~mA} \mathrm{mg}^{-1} \mathrm{Pt}\end{array}$ & 41 \\
\hline $\mathrm{Pt}$ & $\mathrm{H}_{2} \mathrm{PtCl}_{6}, \mathrm{EG}$ & $750 \mathrm{~W}-2 \mathrm{~min}$ & $\begin{array}{l}\text { nanoparticles } \\
4 \mathrm{~nm} \text { in width and 5- } \\
10 \mathrm{~nm} \text { in length }\end{array}$ & $\begin{array}{l}\mathrm{MO}: \\
E_{\mathrm{f}}=0.65 \mathrm{~V}\end{array}$ & 42 \\
\hline $\mathrm{Pt} / \mathrm{Cu}_{2} \mathrm{O}$ & $\mathrm{K}_{2} \mathrm{PtCl}_{4}$ & $240 \mathrm{~W}-6 \mathrm{~min}$ & $4.0 \mathrm{~nm}-\mathrm{Pt} / \mathrm{Cu}_{2} \mathrm{O}$ & MO: & 43 \\
\hline $\mathrm{Pd} / \mathrm{Cu}_{2} \mathrm{O}$ & $\begin{array}{l}\mathrm{K}_{2} \mathrm{PdCl}_{4} \\
\mathrm{Cu}(\mathrm{AC})_{2}\end{array}$ & & $9.6 \mathrm{~nm}-\mathrm{Pd} / \mathrm{Cu}_{2} \mathrm{O}$ & $\begin{array}{l}I_{\mathrm{f}}=1321.9 \mathrm{~mA} \mathrm{mg}-1 \mathrm{Pt} \\
\left(\mathrm{Pt} / \mathrm{Cu}_{2} \mathrm{O}\right) ; 718.0 \mathrm{~mA} \mathrm{mg}^{-1} \\
\mathrm{Pd}\left(\mathrm{Pd} / \mathrm{Cu}_{2} \mathrm{O}\right)\end{array}$ & \\
\hline PtNi & $\begin{array}{l}\mathrm{H}_{2} \mathrm{PtCl}_{6}, \\
\mathrm{Ni}\left(\mathrm{NO}_{3}\right)_{2,} \mathrm{EG}\end{array}$ & Pulse mode-700 W & $\begin{array}{l}2.5-2.7 \mathrm{~nm} \\
\text { nanoparticles }\end{array}$ & $\begin{array}{l}\text { MO: } \\
l_{f} / /_{b}=0.81-0.86\end{array}$ & 44 \\
\hline PtNi & $\begin{array}{l}\mathrm{H}_{2} \mathrm{PtCl}_{61} \\
\mathrm{Ni}\left(\mathrm{NO}_{3}\right)_{2,} \mathrm{EG}\end{array}$ & $\begin{array}{l}\text { Continues mode- } 700 \\
\text { W }\end{array}$ & $\begin{array}{l}\text { 3.2-3.3 nm } \\
\text { Nanoparticles }\end{array}$ & $\begin{array}{l}\text { MO: } \\
l_{f} / l_{b}=0.75-1.1\end{array}$ & 44 \\
\hline PtRu & $\begin{array}{l}\mathrm{H}_{2} \mathrm{PtCl}_{6,} \\
\mathrm{RuCl}_{3,} \\
\text { ethanol, } \mathrm{H}_{2} \mathrm{O}\end{array}$ & $300 \mathrm{~W}-4 \mathrm{~min}$ & $\begin{array}{l}\text { 3.1-7.7 nm } \\
\text { nanoparticles }\end{array}$ & $\begin{array}{l}\text { MO: } \\
l_{f} / l_{b}=0.88-1.65\end{array}$ & 45 \\
\hline $\mathrm{Pt} / \mathrm{Ni}(\mathrm{OH})_{2}$ & $\begin{array}{l}\mathrm{Ni}(\mathrm{Ac})_{2}, \mathrm{EG} \\
\mathrm{H}_{2} \mathrm{PtCl}_{6} \text { and } \\
\text { poly(methacr } \\
\text { ylic acid) }\end{array}$ & $800 \mathrm{~W}-90 \mathrm{~s}$ & $2 \mathrm{~nm}$ nanoparticles & $\begin{array}{l}\text { MO: } \\
I_{\mathrm{f}}=1236 \mathrm{~mA} \mathrm{mg}^{-1} \mathrm{Pt}\end{array}$ & 36 \\
\hline PtRu & $\begin{array}{l}\mathrm{H}_{2} \mathrm{PtCl}_{6,} \\
\mathrm{RuCl}_{3}, \mathrm{EG}\end{array}$ & $163^{\circ} \mathrm{C}-3 \mathrm{~min}$ & $2.8 \mathrm{~nm}$ nanoparticles & $\begin{array}{l}\text { MO: } \\
I_{\text {mass }}=20 \mathrm{~A} \mathrm{~g}^{-1} @ 0.4 \mathrm{~V}\end{array}$ & 34 \\
\hline
\end{tabular}




\begin{tabular}{|c|c|c|c|c|c|}
\hline PtSn & $\begin{array}{l}\mathrm{H}_{2} \mathrm{PtCl}_{6}, \mathrm{SnCl}_{2}, \\
\mathrm{EG} \text {, ethanol, } \\
\text { or propylene } \\
\text { glycol }\end{array}$ & $800 w-60 s$ & $\begin{array}{l}\text { 2.9-8.1 nm } \\
\text { Nanoparticles }\end{array}$ & $\begin{array}{l}\text { EO: } \\
I_{\text {mass }}=12.2 \mathrm{~A} \mathrm{~g}^{-1} \mathrm{Pt}\end{array}$ & 46 \\
\hline $\mathrm{Pt} / \mathrm{SnO}_{2}$ & $\begin{array}{l}\mathrm{H}_{2} \mathrm{PtCl}_{6,} \mathrm{SnO}_{2}, \\
\mathrm{EG}\end{array}$ & $140^{\circ} \mathrm{C}-5 \mathrm{~min}$ & $\begin{array}{l}\text { 3- } 4 \mathrm{~nm} \mathrm{Pt} \\
\text { nanoparticles }\end{array}$ & $\begin{array}{l}\text { EO: } \\
I_{\text {mass }}=180 \mathrm{~A} \mathrm{~g}^{-1} \mathrm{Pt}\end{array}$ & 47 \\
\hline $\mathrm{PtNi}$ & $\mathrm{H}_{2} \mathrm{PtCl}_{6,}$ & $800 \mathrm{~W}-60 \mathrm{~s}$ & $\sim 2.5 \mathrm{~nm}$ nanoparticles & EO: Imass= & 30 \\
\hline PtRu & $\mathrm{SnCl}_{2}, \mathrm{RuCl}_{3}$, & & & $0.62 \mathrm{~A} \mathrm{~g}^{-1} \mathrm{Pt}(\mathrm{PtNi})$ & \\
\hline PtRuNi & $\mathrm{NiCl}_{2}, \mathrm{EG}$ & & & $1.83 \mathrm{~A} \mathrm{~g}^{-1} \mathrm{Pt}(\mathrm{PtRu})$ & \\
\hline PtSnRuNi & & & & $\begin{array}{l}\text { 1.46 } \mathrm{A} \mathrm{g}^{-1} \mathrm{Pt}(\text { PtRuNi) } \\
7.25 \mathrm{~A} \mathrm{~g}^{-1} \mathrm{Pt}(\mathrm{PtSnRuNi})\end{array}$ & \\
\hline $\mathrm{Pd}$ & $\begin{array}{l}\mathrm{PdCl}_{2} \text {, citric } \\
\text { acid, }\end{array}$ & $650 \mathrm{~W}-5 \mathrm{~min}$ & 7 nm nanoparticles & $\begin{array}{l}\text { EO: } \\
l_{f} / l_{b}=0.86\end{array}$ & 48 \\
\hline $\begin{array}{l}\mathrm{Pd} / \mathrm{FeCo} @ \\
\mathrm{Fe}\end{array}$ & $\begin{array}{l}\mathrm{FeCl}_{2,} \mathrm{CoCl}_{2,} \\
\mathrm{PdCl}_{2}, \mathrm{EG}, \\
\text { Polyvinylpyrr } \\
\text { olidone }\end{array}$ & $\begin{array}{l}500 \mathrm{~W}, 80 \text { bars, } 198^{\circ} \mathrm{C} \\
-15 \mathrm{~min}\end{array}$ & $\begin{array}{l}7.4-10.8 \mathrm{~nm} \\
\text { nanoparticles }\end{array}$ & $\begin{array}{l}\text { EGO: } l_{f} / l_{b}=2.05-3.01 \\
\text { GLYO: } l_{f} / l_{b}=3.05-4.09\end{array}$ & 35 \\
\hline $\begin{array}{l}\mathrm{PdM} / \mathrm{C}(\mathrm{M} \\
=\mathrm{Ru}, \mathrm{Ni}\end{array}$ & $\begin{array}{l}\mathrm{PdCl}_{2}, \mathrm{SnCl}_{2}, \\
\mathrm{RuCl}_{3}, \mathrm{NiCl}_{2},\end{array}$ & Pulse mode-800 W & $\begin{array}{l}\text { 3.1-4.9 nm } \\
\text { nanoparticles }\end{array}$ & $\begin{array}{l}\text { GLYO: Imass }= \\
72 \mathrm{~A} \mathrm{~g}^{-1} \mathrm{Pd}(\mathrm{PdRu})\end{array}$ & 49 \\
\hline Sn, Mn, & $\mathrm{FeCl}_{3}, \mathrm{MnCl}_{2}$ & & & $93 \mathrm{~A} \mathrm{~g}^{-1} \mathrm{Pd}(\mathrm{PdNi})$ & \\
\hline $\mathrm{Fe})$ & $\begin{array}{l}\text { propylene } \\
\text { glycol, } \\
\mathrm{NaOH}\end{array}$ & & & $\begin{array}{l}80 \mathrm{~A} \mathrm{~g}^{-1} \mathrm{Pd}(\mathrm{PdSn}) \\
39 \mathrm{~A} \mathrm{~g}^{-1} \mathrm{Pd}(\mathrm{PdMn}) \\
80 \mathrm{~A} \mathrm{~g}^{-1} \mathrm{Pd}(\mathrm{PdFe})\end{array}$ & \\
\hline $\begin{array}{l}\text { PtRu } \\
\mathrm{PdRu}\end{array}$ & $\begin{array}{l}\mathrm{PdCl}_{2}, \mathrm{H}_{2} \mathrm{PtCl}_{6 r} \\
\mathrm{RuCl}_{3,} \\
\text { propylene } \\
\text { glycol }\end{array}$ & Pulse mode-800 W & $\begin{array}{l}\text { 2.47-4.55 nm } \\
\text { Nanoparticles }\end{array}$ & GLYO & 50 \\
\hline
\end{tabular}

Table 2 Microwave-assisted synthesis of typical metal nanocatalysts for electrochemical oxidation of 
formic acid and glucose. FAO: formic acid oxidation; GO: glucose oxidation; EG: ethylene glycol. $I_{\mathrm{f}}$ : forward peak current; $I_{\mathrm{b}}$ : backward peak current; $E_{\mathrm{f}}$ : forward peak potential; $E_{\mathrm{onset}}$ onset overpotential; $I_{\text {mass }}$ : mass activity; $P_{\max }$ : maximum power of single cell.

\begin{tabular}{|c|c|c|c|c|c|}
\hline Metal & Precursors & Reaction conditions & Size/morphology & Catalytic properties & Ref. \\
\hline $\mathrm{PtPb}$ & $\begin{array}{l}\mathrm{H}_{2} \mathrm{PtCl}_{6}, \quad \mathrm{EG} \\
\mathrm{Pb}\left(\mathrm{CH}_{3} \mathrm{COO}\right)_{2}\end{array}$ & $800 \mathrm{~W}-90 \mathrm{~s}-5 \mathrm{~min}$ & $5.9 \mathrm{~nm}$ spheres & $\begin{array}{l}\text { FAO: } \\
I_{\mathrm{f}}=1139.1 \mathrm{~mA} \mathrm{mg}^{-1} \mathrm{Pt}\end{array}$ & 38 \\
\hline PtAu & $\begin{array}{l}\mathrm{H}_{2} \mathrm{PtCl}_{6,} \\
\mathrm{HAuCl}_{4} \\
\mathrm{Na}_{3} \mathrm{C}_{6} \mathrm{H}_{5} \mathrm{O}_{7}\end{array}$ & $150^{\circ} \mathrm{C}-6 \mathrm{~min}-10 \mathrm{bar}$ & $\begin{array}{l}\sim 2 \mathrm{~nm} \text { nanoparticles } \\
\text { agglomeration }\end{array}$ & $\begin{array}{l}\text { FAO: } \\
E_{\text {onset }}=0.218-0.348 \mathrm{~V}\end{array}$ & 51 \\
\hline $\mathrm{Pd}$ & $\begin{array}{l}\mathrm{H}_{2} \mathrm{PtCl}_{6,} \mathrm{PdCl}_{2,} \\
\mathrm{EG}, \mathrm{KOH}\end{array}$ & $700 \mathrm{~W}-50 \mathrm{~s}$ & $\begin{array}{l}4 \mathrm{~nm} \text { nanoparticles } \\
5 \mathrm{~nm} \text { nanoparticles }\end{array}$ & $\begin{array}{l}\text { FAO: } \\
\text { single cell @ } 25^{\circ} \mathrm{C}: \\
P_{\max }=120 \mathrm{~mW} \mathrm{~cm}^{-2}(\mathrm{Pt}) \\
76.5 \mathrm{~mW} \mathrm{~cm}^{-2}(\mathrm{Pd})\end{array}$ & 52 \\
\hline $\mathrm{PdAu}$ & $\begin{array}{l}\mathrm{PdCl}_{2}, \mathrm{HAuCl}_{4}, \\
\mathrm{EG}\end{array}$ & Pulse mode & $\begin{array}{l}\text { 6.6-9.7 nm } \\
\text { nanoparticles }\end{array}$ & GO & 53 \\
\hline $\mathrm{PdAu}$ & $\begin{array}{l}\mathrm{PdCl}_{2}, \mathrm{HAuCl}_{4}, \\
\mathrm{EG}\end{array}$ & Pulse mode & $\begin{array}{l}\text { 4.4-4.8 } \mathrm{nm} \\
\text { nanoparticles }\end{array}$ & GO & 54 \\
\hline PdRh & $\begin{array}{l}\mathrm{PdCl}_{2}, \mathrm{RhCl}_{3}, \\
\mathrm{EG}, \mathrm{NaOH}\end{array}$ & Pulse mode & $\begin{array}{l}\text { 5-12 nm } \\
\text { Nanoparticles }\end{array}$ & $\begin{array}{l}\mathrm{GO}: \\
I_{\mathrm{f}}=1.7-3.5 \mathrm{~mA} \mathrm{~cm}^{-2} ; \\
l_{b}=0.2-0.9 \mathrm{~mA} \mathrm{~cm}^{-2}\end{array}$ & 55 \\
\hline
\end{tabular}

